\title{
23 Waste pickers and their right to the city
}

\author{
Dispossession and displacement in \\ nineteenth-century Paris and \\ contemporary Montevideo
}

\author{
Lucía Fernandez
}

\section{Introduction}

We were sitting for decades over a pile of gold without really noticing ... now they are aware of it and are coming for our waste.

(Alex Cardoso, Brazilian catador during Expocatadores, Brazil, 2013)

In recent decades, owners of capital have been looking at waste management as a new, emerging, high-yielding global market. The challenge of managing an increasing amount of waste represents an opportunity for profit-making for both existing and new businesses (World Bank 2012). In sum, waste management has become a multimillion-dollar industry.

Driven both by profit-making and urban paradigms of modern hygienic cities (Harpet 1997; Barles 2005; Abussafy 2013), technological solutions to the challenge of collecting, transporting, disposing of and treating waste are being adopted by cities around the world. In the process, the competition for waste, for recyclable materials and waste management contracts, has intensified; and the livelihoods of traditional waste pickers, and their knowledge of recycling, are under threat. Around the world, cities are privatizing waste management and, in so doing, dispossessing traditional waste pickers of their right to access and recycle waste, thus creating a fight for the appropriation of waste (Samson 2009, 2014). To paraphrase David Harvey (2004), accumulation of capital (in this case waste) by some actors leads to dispossession of capital (waste) for others.

This competition for waste, for recyclable materials and for waste management contracts can be understood as a competition for the right to the city and its resources. The French philosopher Lefebvre argued that urban space is an object and instrument of confrontation and conflict, and at the same time a means of production and a means of control - of domination and power - where various interests compete, leading to clashes over appropriation and use of urban space (Lefebvre 1974). Over the past decade or more, in the spirit of Lefebvre, a right to the city movement has emerged to challenge the capitalist order, to seek a 
radical restructuring of social, political, and economic relationships in the city (Lefebvre 1968; Purcell 2003).

This chapter illustrates how the accumulation of waste, and waste management, by powerful groups, institutions, and elites lead to dispossession of waste for traditional waste pickers, undermining their access to waste and to public space and their right to transit freely within the city. In the process the system of waste management established by the traditional waste pickers, what some observers have called socioeconomic metabolic systems ${ }^{1}$ (Martinez-Alier, 2009; Veronesi, 2016; Demaria, 2017) or recylingscape (Samson 2017 and Chapter 25 in this volume), is being disrupted and displaced, and municipalities refuse to acknowledge the waste management and recyling system created by the waste pickers.

To understand the conflicts around waste management and how waste pickers operate in urban space, in particular in public space, I will analyse a set of public resolutions in Paris, France, in the late nineteenth century and Montevideo, Uruguay, between 2012 and 2017: both of which undermined the access of waste pickers, an emblematic group of the urban poor, to recyclable materials as well as their access to the center of their cities.

\section{Normalizing space and time of waste in Paris}

Roughly the same number of waste pickers collected waste from the streets of Paris in the late nineteenth century, as do so in Montevideo today. In Paris, in 1884, according to the official census, ${ }^{2}$ there were around 7,050 chiffoniers (waste pickers) which means around 34,000 persons, lived off collecting and recycling waste as a family-based business; who collected about 130,200 tons of waste per year generating around 70,000 francs per day in waste-picker incomes, and almost 5 million francs per year for the entire recycling and recovery industry. ${ }^{3}$ Indeed, 85 percent of the reclaimed materials that went into the recycling industry came from the work of picking and sorting done by the Parisian chiffonniers.

But over a few decades, following the plans of Baron Haussmann, a civil servant and politician, to "modernize Paris", the city shifted toward capital speculation (Harvey 2008a: 458) which led to displacements of the urban poor from downtown areas to the city's periphery/outskirts. The very first waste container, which carried the name of the city mayor, Eugène-René Poubelle, was introduced in 1870 to normalize both the space in which domestic waste must be placed, as well as the time it should be placed, namely, outside on the street right before the passage of the waste truck. In 1883, a public ruling, again from mayor Poubelle, prohibited waste pickers from emptying the waste containers on the public highway, or placing any of the contents outside the container to find what might be suitable for reclaiming.

The Poubelle ruling led to the founding of an association of chiffonniers, called the "Chambre Syndicale des Chiffonniers" which characterized the threat posed by the ruling to the traditional recycling system as follows: 
A head of household with his wife and three children earned 10 Frs a day or 2 Frs per person on average. Since garbage can no longer be dumped on public roads, $50 \%$ of the materials used by chiffoniers is lost to the French recycling industry. And instead of 2 Frs a day, the chiffonniers scarcely earn $1 \mathrm{Fr} .$. Here is the crisis we are undergoing. ${ }^{4}$

This crisis was not only economical but was also territorial. In order to modernize the collection system and to privatize it for the benefit of specialized companies, the chiffoniers began to be displaced, not only from their homes, but also from their working space (Lortie 1992; Kamoun 2000; Barles 2005). The collection and disposal of waste in the entire city, and particularly in the richest areas of Paris where the most valuable recoverable waste was to be found, were granted to a company that signed a contract with the state. ${ }^{5}$

The future of "modern" waste management finds its beginnings in this ruling from the late nineteenth century. As the years passed and as Paris kept growing, the chiffoniers continued to lose their right to the city (Harvey 2008b), manifested in their confinement to the periphery and their inability to access and enjoy Paris intramuros (Figure 23.1). From an ecological perspective, this shift came with a dramatic change in the city's urban metabolism as modern waste management systems no longer engaged in recycling (as the chiffoniers used to promote). Waste disposal was centralized into a series of new incinerators, further undermining the ability of waste pickers to recover and recycle waste and the air quality of the city.

\section{Territorial displacement of clasificadores in Montevideo}

A neighbor from Buceo called me and gave me a 29-inch TV that still works! If they take us off the street, people do not understand that we lose all these opportunities, which are not quantifiable at an economic level, but in our own quality of life and our relationship with our neighbors.

(Juan Carlos Silva, clasificador, president of the Trade Union in

Montevideo, interview 30 November 2015)

In Montevideo today, a city where thousands ${ }^{6}$ of waste pickers (clasificadores) have, historically, recycled everything that they could access, ${ }^{7}$ capitalism, disguised in public policies with the support of a very progressive government, reproduces the same exclusionary practices as in Paris in the late nineteenth century. Since 2003, when new waste containers first appeared in public space, many waste pickers are no longer able to visit downtown areas for recovery purposes (Figure 23.2). The practice of limiting access to the richest areas of the city, and to the waste that is produced there, has been intensified since the new system of "hermetic containers" was first introduced in 2015 and since horse carts were banned in 2013 from entering the old downtown which was reconfigured as an exclusionary zone. In addition, waste produced by large generators such as hotels, restaurants, shopping malls, which comprises mostly valuable 


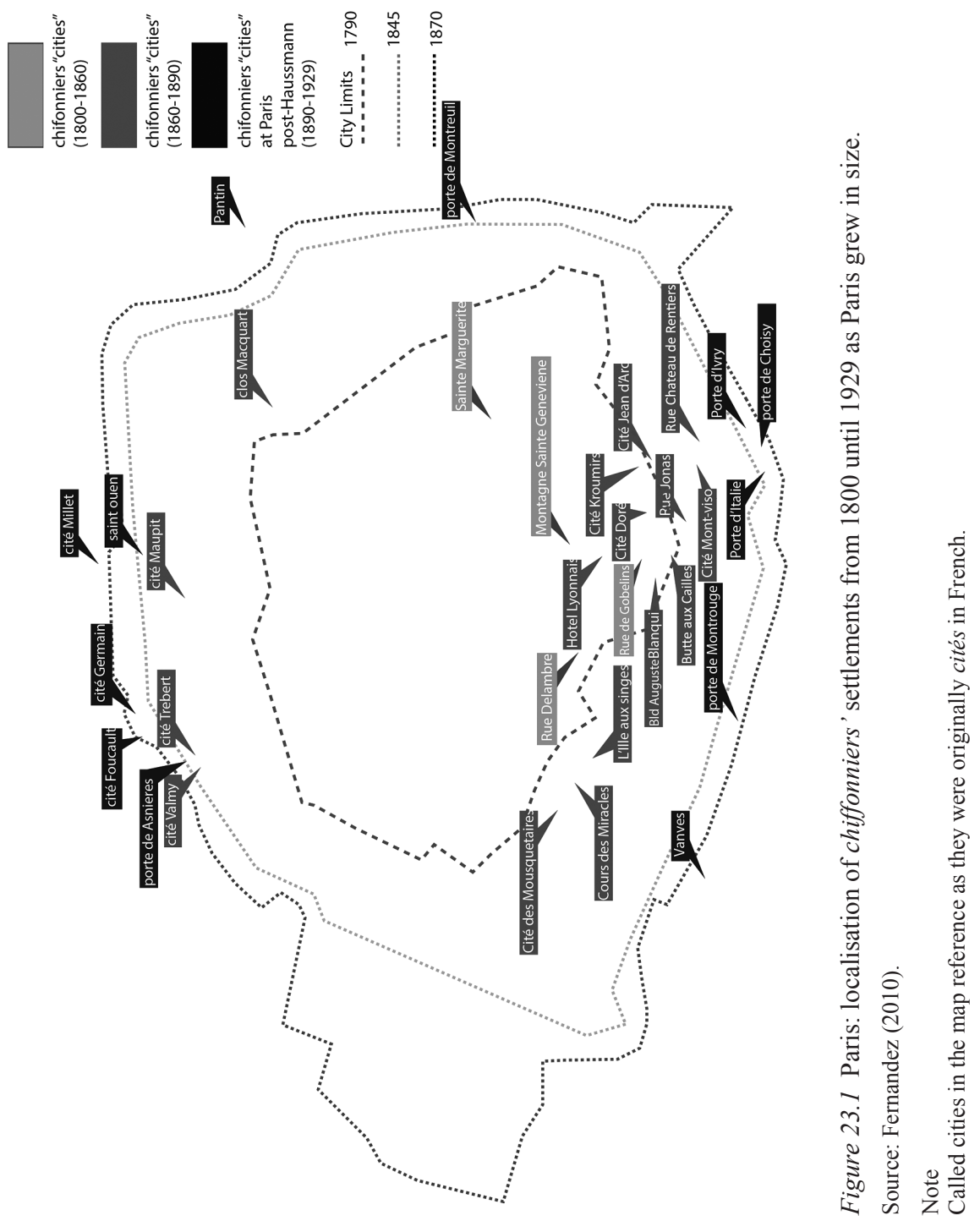







recyclable materials, has become the exclusive domain of private companies or individuals driving motorized vehicles, after a rule was passed in 2012 to "formalize" what waste pickers had done for decades. This set of policies implies, among others, the rupture of a system of social relations that used to link waste pickers with more than 3,000 "clients" (Barrenechea and Gonzalez 2003) in the city who used to offer their waste "for free" through a solidarity system. The new formal enterprises get paid for the amount of waste they collect and dispose of, leading to a significant decrease in recycling rates as they simply dispose of the recyclable materials into the sanitary landfill, rather than reclaiming them. ${ }^{8}$ Therefore, the urban metabolism of the city is again affected by undermining access to recyclables for those who historically reclaimed and recycled them. This new set of policies, in addition to being insufficient in terms of recycling and exclusionary of waste pickers, ${ }^{9}$ implies a profound dislocation of these workers from urban space and, indeed, their city, confining them to the urban periphery where they can devote themselves to sorting and selling materials at the new sorting centers built by the municipality through the Packaging Law established in 2009, where industry responsible for producing large amounts of packaging is now responsible for their waste and needs to pay the state a proportion of funds to cover the costs of formal recycling.

\section{Expanding the notion of commons in the city as social factory}

To conclude, the right to the city becomes for waste pickers essentially the right to centrality, to use and appropriate public space, and not to be excluded from the urban form. As Lefebvre (1968) argued, by excluding groups and classes from "urbanity", we are also excluding them from civilisation and society. Therefore, claiming the right to the city for waste pickers is a legitimate reaction to an increasingly discriminatory and segregated urban paradigm associated with the privatization of waste and its management and other policies on the use of space. In addressing the urban roots of the May 1968 movement in Paris, Lefebvre argued that capital has moved beyond the factory walls and as a result the city has become "the social factory". ${ }^{10}$ Hardt and Negri (2001) argued that the metropolis is to the multitude what the factory was to the working class. Regarding informal waste pickers, most of whom are territorially and organizationally dispersed, it is crucial to understand that while the struggles of the "workers" are aimed at improving working conditions, mobilizations against waste dispossession are aimed at claiming and recovering common public goods, as a condition to make life - and livelihoods - possible in the great social factory that is the city (Castro Coma and Martí Costa 2016).

The main theoretical challenge would be to expand the notion of common goods to include waste as a commons (Cavé 2012, 2015; Zapata and Zapata 2015; O'Hare 2017) to critically analyse the relations between those who produce waste (citizens) or improve it at various scales (waste pickers/recyclers) and those who appropriate it for profit (private collection companies). The concept of commons should then be framed not as an object but as what is 
produced collectively (Federici 2012; Heller 2012), over which control or management is not delegated to an outside social body but is exercised directly by those who produce it. The strength of the commons understood in this sense lies in the fact that its production allows us to think about the possibility of generating something new, to create new forms of reproduction, organization, and regulation of collective life and public governance.

To spatialize these commons, to think of them from the urban space perspective, helps us understand the power and collaborative relationships among the actors related to waste management. The recognition of the work, services and contributions of waste pickers in the city must be affirmed through a new type of community that manages its urban resources in a sustainable way. Samson (2015a) and Chikarmane (2016) argue that by mobilizing collectively to demand formal incorporation into municipal waste management systems, waste pickers are expanding both the public sector and the public sphere, transforming relations between the state, the formal economy, the informal economy and residents, and contributing to the forging of a more inclusive, participatory and democratic state. The rights of waste pickers as citizens and workers, including linking them with other residents of the city through the management of waste, are fundamental for living in a healthy and democratic city that is inclusive of all its inhabitants.

Following the "right to the city" concept and a new understanding of the urban space, these principles and practice of communal ownership will help us frame a potentially radically different model of municipal waste management and governance. This new management and governance model, in which waste is produced, managed and controlled by the community, is based on a new interpretation of what is public or common; it challenges the notion of a centralized state by pushing for a system that is capable of managing a complex and decentralized communalism (Bookchin 2006).

\section{Notes}

1 What follows this concept, and according to a dialectical vision, is the understanding of urban metabolism as a mutually constructive conception of the relations between nature and urban society, where nature is metabolically transmuted through urban space according to its historical processes (Swyngedouw and Kaika 2000). Therefore, in exercising power over ecological and social flows, human beings are active players in the evolution of the city.

2 According to the "Hygienic Research Commission" published in the Official Bulletin of 1886 (Barberet 1886: 84).

3 See Fontaine (1903: 17).

4 Excerpt from the statement of Mr. Potin, chiffonnier leader, to the Parliamentary Commission, March 11, 1884 (Barberet 1886: 70).

5 "Art. 21 - All the products contained in the receptacles, deposited by the local residents or projected illicitly on the public road, will belong to the contractor who will draw such a part as it will judge suitable, either by transporting them outside to be delivered to the farmer, either by turning them into factories by cremation or by any other method ..." (Excerpt from the specifications of the company for the removal of sludge and garbage and residues sweeping Paris, from 1891 to 1899; Fontaine, 1903: 73). 


\section{Lucía Fernandez}

6 From 3,500 waste pickers during stable or positive economic scenarios, to more than 10,000 as a result of the economic crisis suffered in 2003.

7 Similar to numbers in Brazil, it has been proved that almost 90 percent of what is recycled in the city was thanks to waste pickers at the bottom of the pyramid (2006 study by the national government).

8 There is very little economic rentability for them to spend time and resources on sorting waste, as most of the value generation came from the high rates charged for collection.

9 From the thousands who have lost their income (the approximate number is under investigation), only 128 waste pickers are formalized and working in four new places, which are located, as shown in Figure 23.2, far from downtown, near their homes.

10 The social factory is a concept developed by the Italian autonomist Marxist Mario Tronti in his book, Factory and Society (1962), to help analyse how capitalist social relations had expanded outside the sphere of production to that of society as a whole. 